\title{
Literasi Media Mahasiswa Perguruan Tinggi Negeri Kota Kendari Terhadap Isu Sara Pada Media Sosial
}

\author{
Sri Hadijah Arnus \\ Fakultas Ushuluddin, Adab, dan Dakwah Institut Agama Islam Negeri \\ Kendari, Indonesia \\ hadijaharnus@gmail.com
}

\begin{abstract}
This study aims to analyze literacy media among state university students in Kendari regarding the issue of SARA in social media and to provide solutions to enhance the student's media literacy skills. This study is design in descriptive qualitative approach. Required data for this study were collected through snowball sampling. Data analysis was carried out using Individual Competence Framework. This study reveals that the level of media literacy skills of the students was classified as basic. In other words, the students had basic skills to utilize the media and had limited media usage. The users understood the basic functions, reveal the basic codes and use them for final objectives. The students' ability to critically analyze the received information was limited. As a result, the ability to communicate through the media was also limited. The solutions to improving media literacy skills of state university students in Kendari can be through incorporating knowledge regarding media literacy in the curriculum of study programs, conducting research related to media literacy among lecturers and students, holding trainings and workshops, providing media literacy knowledge through leader opinions such as religious leaders and community leaders, and developing religious studies on campus.
\end{abstract}

Keyword: media literacy; social media.

\begin{abstract}
Abstrak
penelitian ini bertujuan untuk menganalisis literasi media mahasiswa perguruan tinggi negeri di Kota Kendari terhadap isu SARA pada media sosial dan solusi dalam meningkatkan kemampuan literasi media mahasiswa tersebut. Jenis penelitian ini adalah deskriptif kualitatif. Teknik pengumpulan data dengan carasnowball sampling. Teknis Analisis data dilakukan dengan menggunakan Individual Competence Framework. Berdasarkan hasil penelitian dapat dilihat bahwa kemampuan literasi media mahasiswa perguruan tinggi negeri di Kota Kendari masih berada pada tingkat basic atau dasar, dimana mereka memiliki kemampuan yang memungkinkan dalam penggunaan dasar media. Penggunaan media masih terbatas. Pengguna mengetahui fungsi dasarnya, memecah kode dasarnya dan menggunakannya untuk tujuan akhir. Kemampuan pengguna untuk menganalisis secara kritis informasi yang diterima terbatas. Kapabalitas komunikasinya melalui media juga terbatas.Solusi dalam meningkatkan
\end{abstract}


kemampuan literasi media pada mahasiswa perguruan tinggi negeri di kota Kendari dapat dilakukan dengan memasukkan pengetahuan mengenai literasi media pada kurikulum pendidikan disetiap program studi, melakukan penelitian terkait literasi media di kalangan dosen maupun mahasiswa, mengadakan pelatihan dan workshop, memberikan pengetahuan literasi media melalui opinion leader baik itu pemuka agama ataupun tokoh masyarakat,serta mengembangkan kajian-kajian agama di kampus.

Kata Kunci: Isu SARA; media literasi, sosial media.

\section{A. Pendahuluan}

Perkembangan teknologi komunikasi dan informasi yang sangat pesat, membawa perubahan pada pola komunikasi di masyarakat saat ini. Bentuk dari perkembangan teknologi komunikasi dan informasi adalah lahirnya media baru yang berbasis internet. Salah satu fitur dari media baru yang menjadi tren di masyarakat saat ini adalah media sosial. Masyarakat Pengguna media sosial dapat mencari informasi dan berinteraksi di media tersebut. Munculnya media sosial membawa perubahan penggunaan media di masyarakat, yang dahulu mengandalkan media konvensional (tv, radio, surat kabar, majalah, dan sejenisnya) dalam memperoleh informasi. Salah satu perbedaan antara media sosial dan media massa konvensional adalah dari segi pengawasan terhadap konten media yang disampaikan kepada khalayak. Pengawasan pada media massa konvensional yang dikelola oleh sebuah lembaga media dilakukan oleh pemerintah. Selain itu terdapat elemen-elemen pada media massa konvensional yaitu gatekeeper dan regulator yang berperan dalam memilah pesan yang layak atau tidak layak untuk disampaikan kepada khalayak.

Pengawasan ketat yang dilakukan oleh pemerintah layaknya pada media massa konvensional tidak dapat dilakukan secara maksimal pada media baru, dalam hal ini media sosial. Hal ini disebabkan karena setiap orang dapat mengakses internet tanpa ada batasan negara maupun teritorial. Setiap pengguna media sosial dapat menikmati informasi maupun dapat menyebarluaskan informasi, hal ini dikarenakan sifat desentralized dan tingginya interaktivitas pada media sosial. Sifat desentralized membuat pengguna media sosial tidak hanya pasif menerima berita ataupun informasi, akan tetapi juga dapat menyebarluaskan informasi kepada pengguna media sosial lainnya. Tingginya interaktivitas pada media sosial memungkinkan pengguna media sosial dapat berkomunikasi dan berinteraksi dengan siapa saja yang tidak dibatasi oleh ruang dan waktu ${ }^{1}$. Hal ini karena didukung oleh

${ }^{1}$ Apriadi Tamburaka. Literasi Media, Cerdas Bermedia Khalayak Media Massa. (Jakarta: Rajawali Pers. 2013). h. 20 
fitur-fitur pada media sosial yang terus berkembang, yang memudahkan pengguna dalam mengaplikasikan media sosial. Hal ini berbeda dengan media massa konvensional yang bersifat one way communications sehingga mengakibatkan feedbback khalayak tertunda.

Keberagaman suku, agama, dan etnis di Indonesia menjadikan isu tentang SARA menjadi hal yang sangat sensitif. Suku, agama, ras, dan golongan merupakan suatu identitas yang melekat pada diri setiap individu .Manusia umumnya mengidentifikasikan diri dengan kelompok dan ideologi kelompok. Kita kemudian melakukan pengelompokan yang berbeda agama, bahkan yang memiliki agama yang sama tetapi berbeda aliran, dapat dianggap berbeda oleh kelompok. Dalam kondisi ada emosi-emosi negatif terjadilah penilaian yang makin bersifat emosional. Kelompok sendiri dianggap lebih dapat dipercaya, kelompok lain dilihat tidak dapat dipercaya dan mengancam. Prasangka mengahadirkan sikap-sikap yang membedakan atau diskriminatif pada kelompok yang dianggap berbeda. Banyaknya konten media yang berisi kebencian dan mengklaim merasa paling benar membuat isu tentang agama, suku, ras menjadi sangat sensitif ${ }^{2}$. Hal inilah sehingga isu SARA kerap digunakan oleh segelintir pihak tertentu untuk mencapai berbagai tujuan, contohnya saja isu SARA dapat digunakan dalam mencapai tujuan politik, tujuan bisnis, atau memprovokasi massa untuk kepentingan pihak tertentu.

Kemampuan kritis terhadap konten media disebut dengan kemampuan literasi media. Literasi media berasal dari bahasa Inggris yaitu media literacy, yang terdiri dari dua kata yaitu 'media' yang apabila diartikan dari konteks komunikasi berarti tempat pertukaran pesan dan litercy berarti melek. Literasi media merujuk kemampuan khalayak dalam melek terhadap pesan media massa ${ }^{3}$. Literasi media berhubungan dengan bagaimana khalayak dapat mengambil kontrol atas media. Literasi media merupakan skill untuk menilai makna dalam setiap jenis pesan, mengorganisasikan makna itu sehingga beguna, dan kemudian membangun pesan untuk disampaikan kepada orang lain. Potter ${ }^{4}$ menekankan bahwa literasi media dibangun dari personal locus, struktur pengetahuan dan skill. Personal locus merupakan tujuan dan kendali kita akan informasi. Ketika kita menyadari akan informasi yang kita butuhkan, maka kesadaran kita akan menuntun untuk melakukan proses pemilihan informasi secara lebih cepat, pun sebaliknya. Struktur pengetahuan merupakan seperangkat informasi yang

\footnotetext{
${ }^{2}$ Poerwandari, "Rubrik Psikologi”, Harian Kompas, Sabtu, 29 Juli 2017, h. 25

${ }^{3}$ Apriadi Tamburaka, Literasi Media... Op Cit. 7

${ }^{4}$ Intania Poerwaningtias, dkk. Model-Model Gerakan Literasi Media dan Pemantauan Media di Indonesia. (PKBP Yogyakarta, 2013), h.16
} 
terorganisir dalam pikiran kita. Dalam literasi media kita membutuhkan struktur informasi yang kuat akan efek media, isi media, industri media, dunia nyata, dan diri kita sendiri sementara skill adalah alat yang kita gunakan untuk meningkatkan kemampuan literasi media kita.

Faktor yang mendorong penelitian untuk menganalisis kemampuan literasi media mahasiswa perguruan tinggi negeri di Kota Kendari karena melihat mahasiswa merupakan kelompok pengguna media sosial yang aktif. Media sosial atau biasa juga disebut dengan media jejaring sosial, menurut Boyd dan Ellison ${ }^{5}$ sebagai layanan berbasis web yang memungkinkan perorangan untuk membangun profil umum atau semi umum dalam satu sistem yang terbatas menampilkan pengguna lainnya yang berkaitan dengan mereka, melihat-lihat dan mengamati daftar koneksi yang mereka miliki maupun daftar yang dibuat oleh pengguna lainnya dalam sistem tersebut. Pendapat lain mengenai media sosial adalah sebuah media online, dimana penggunanya bisa dengan mudah berpartisipasi, berbagi, dan menciptakan isi meliputi blog, jejaring sosial, wiki, forum dan dunia virtual. Blog, jejaring sosial dan wiki merupakan bentuk media sosial yang paling umum digunakan oleh masyarakat di seluruh dunia. Media sosial juga dapat disebut media online yang mendukung interaksi sosial dan menggunakan teknologi berbasis web yang mengubah komunikasi menjadi dialog interaktif. ${ }^{6}$

Mahasiswa masuk kedalam kelompok umur transisi remaja menjelang dewasa. Menurut data menyebutkan bahwa Indonesia merupakan negara pengguna facebook terbesar keempat di dunia setelah Amerika Serikat, Brazil, dan India, sedangkan jumlah pengguna facebook di Indonesia berdasarkan umur menunjukkan bahwa umur 15-26 tahun merupakan kelompok umur yang paling banyak menggunakan facebook ${ }^{7}$, sedangkan pengguna mobile internet, termasuk pengakses internet melalui mobilephone yang paling banyak adalah kelompok usia 18-27 tahun. Mahasiswa merupakan kelompok umur yang masih dalam proses mencari jati diri, sehingga sangat rentan terhadap pengaruh-pengaruh negatif utamanya pengaruh dari media sosial.

Penelitian mengenai kemampuan literasi media telah dilakukan oleh beberapa peneliti sebelumnya diantaranya Juliana Kurniati dan Siti Baroroh ${ }^{8}$

${ }^{5}$ David Mahendra, Media Jejaring Sosial dalam Dimensi Self Disclosure. (Yogyakarta: Skripsi UIN Sunan Kalijaga, 2014), h. 11

${ }^{6}$ Dian Budiargo, Berkomunikasi Ala Net Generations, (Jakarta, PT. Elex Media Kompetindo, 2015), h. 35

${ }^{7}$ Gun Gun Harianto. Media Komunikasi Politik. (Yogyakarta. IRCISod. 2018)

${ }^{8}$ Juliana Kurniawati \& Siti Baroroh, "Literasi Media Digital Mahasiswa Universitas Muhammadiyah Bengkulu". Jurnal Komunikator Vol.8 No.2 (November 2016): 51-66 
yang berjudul Literasi Media Digital Mahasiswa Universitas Muhammadiyah Bengkulu untuk mengetahui sejauh mana pemahaman mahasiswa Universitas Muhammadiyah Bengkulu terhadap media digital dan untuk mengetahui seberapa tingggi tingkat individual competence serta faktor-faktor apa saja yang mempengaruhi tingkat individual competence terkait literasi media, dimana individual competence adalah kemampuan seseorang dalam menggunakan dan memanfaatkan media. Penelitian senada dilakukan oleh Rebekka Purba ${ }^{9}$ yang berjudul Tingkat literasi media pada mahasiswa (studi deskriptif pengukuran tingkat literasi media berbasis individual competence framework pada mahasiswa depeartemen ilmu komunikasi USU). Penelitian ini mengukur tingkat literasi media pada mahasiswa departemen ilmu komunikasi dengan menggunakan indikator Individual competence framework. Penelitian relevan lainnya dilakukan oleh Inda Fitryarini yang berjudul literasi media pada mahasiswa prodi ilmu komunikasi Universitas Mulawarman ${ }^{10}$. Zubaidi menfokuskan pada peran literasi media dalam meminimalisir sinisme antarsuku, agama, ras dan antar golongan ${ }^{11}$. Prasetiyo \& Gunarsi melakukan penelitian tentang upaya literasi muda terhadap fitnah pada organisasi kepemudaan masjid Forsam (Forum Silaturahmi Antar Masjid) di Klaten Selatan dan menemukan bahwa literasi media terhadap organisasi ini menunjukan bahwa mereka mampu mengidentifikasi kekuatan, kelemahan, peluang dan tantangan dalam memetakan objek dakwah terutama dengan memanfaatkan media sosial ${ }^{12}$. Penelitan dengan menfokuskan literasi media pada mahasiswa sebagaimana dilakukan Sulthan \& Istiyanto tentang model-model literasi media sosial bagi mahasiswa Universitas Jenderal Sudirman Purwokerto dan menemukan bahwa mahasiswa menggunakan media sosial sesuai kebutuhan dan kekhasan media sosial yang ada, baik dari bertukar informasi dan menjaga pertemanan hingga alasan proses pembelajaran, ekonomi, hiburan, dan

${ }^{9}$ Rebekka Purba, "Tingkat Literasi Media Pada Mahasiswa (Studi Deskriptif Pengukuran Tingkat Literasi Media Berbasis Individual Competence Framework Pada Mahasiswa Departemen Ilmu Komunikasi USU)", Jurnal Flow, Vol 2, No 9 (2015): 1-10.

10 Inda Fitryarini, "Literasi Media Pada Mahasiswa Prodi Ilmu Komunikasi Universitas Mulawarman”, Jurnal Komunikasi Vol. 8, No. 1, (Juli 2016): 51 - 67

${ }^{11}$ Advan Navis Zubaidi, "Urgensi Literasi Media di Tengah Sinisme Antarsuku, Agama, Ras, dan Golongan”, Jurnal Komunikasi Islam Vol 08, No 01, (Juni 2018): 111-128

12 Wibowo Heru Prasetiyo \& Sri Gunarsi, "Fabrikasi Fitnah Dan Gerakan Dakwah Pemuda: Penguatan Literasi Media Dan Pengelolaan Media Sosial Pada Organisasi Kepemudaan Masjid Forsam Klaten Selatan”, The 9th University Research Colloqium Universitas Muhammadiyah Purworejo, 2019: 54-63 
aktualisasi diri ${ }^{13}$. Mereka juga mengetahui ada dampak negatif dan penyimpangan yang terjadi akibat penggunaan media sosial yang tidak sesuai, namun tidak bisa dielakkan.

Penelitian literasi media baru yang difokuskan pada upaya reduksi berita hoax dan ujaran kebencian yang sangat lekat dan erat dengan isu sara dilakukan Fauzi pada kalangan dosen pengguna Facebook dan Whatsapp di Univesritas Pancasakti Tegal ${ }^{14}$. Penelitian Dedi Rianto Rahadi juga menfokuskan pada perilaku pengguna dan informasi Hoax di Media social ${ }^{15}$.

Beberapa penelitian menfokuskan para penggunaan metode atau media tertentu dalam membangun literasi media dikalangan pemuda. Aulia Rahmawati dan Krisanjaya misalnya melakukan penelitian pada upaya pelatihan literasi media dengan metode getok tular mulut ke mulut sebagai antisipasi terhadap ujaran kebencian pada siswa SMA di Kota Depok menjelang Pemilu Legislatif serta Pemilu Presiden Tahun $2019^{16}$. Penelitian tentang penggunaan metode podo na lima dilakukan oleh Harahap untuk membangun literasi media dalam menfilter berita hoax dengan subjek penelitian pada dosen dan mahasiswa Fakultas Dakwah dan Ilmu Komunikasi IAIN Padangsidimpuan ${ }^{17}$. Ia menemukan bahwa pemahaman dosen dan mahasiswa tentang poda na lima paias rohamu (bersihkan jiwamu) sebagai bentuk konsep literasi media tidak diangkat secara material tetapi lebih pada nilai kandungan dari poda na lima paias rohamu.

Penelitian ini difokuskan pada subjek mahasiswa untuk melihat tingkat literasi media pada mereka, khususnya dalam menghadapi isu sara yang dilayangkan lewat media social. Penelitian ini bagaimanapun dilakukan terhadap sembilan orang mahasiswa Program Studi Ilmu Komunikasi antara dua perguruan tinggi dengan latar agama (IAIN Kendari) dan umum (Universtas Haluoleo) di Kota Kendari dengan mengukur kemampuan

${ }^{13}$ Muhammad Sulthan \& S. Bekti Istiyanto, "Model Literasi Media Sosial Bagi Mahasiswa", Jurnal ASPIKOM, Vol 3 No 6, (Januari 2019): 1076-1092

${ }^{14}$ Ahmad Fauzi, "Memahami Literasi Media Baru dalam Penyebaran Informasi Hoax dan Hate Speech (Studi Fenomenologi Dosen Pengguna Facebook dan Whatsapp)", PROMEDIA, Vol 4, No. 2, (2018): 56 - 76

${ }^{15}$ Dedi Rianto Rahadi, "Perilaku Pengguna dan Informasi Hoax di Media Sosial", Jurnal Manajemen \& Kewirausahaan, Vol. 5, No. 1 (2017): 58-70

16 Aulia Rahmawati \& Krisanjaya, "Pelatihan Literasi Media Dengan Metode Getok Tular Mulut Ke Mulut (Strategi Word Of Mouth Comunication) Untuk Antisipasi Ujaran Kebencian (Hate Speech) Se Kota Depok Provinsi Jawa Barat", Sarwahita : Jurnal Pengabdian Kepada Masyarakat Vol. 15 No. 2 (2018): 106-112

${ }^{17}$ Barkah Hadamean Harahap, "Poda Na Lima Sebagai Konsep Literasi Media Dalam Memfilterisasi Berita Hoax (Studi Pada Dosen dan Mahasiswa Fakultas Dakwah dan Ilmu Komunikasi IAIN Padangsidimpuan)", TAZKIR: Jurnal Penelitian Ilmu-Ilmu Sosial dan Keislaman Vol. 04 No. 2 (Desember 2018): 363-380. 
literasi media berdasarkan indikator kemampuan mengakses media, kemampuan menganalisis media, kemampuan mengevaluasi media dan content creations dengan indikator yang lebih kompleks, utamanya dengan menggunakan framework Individual Competence. Apabila melihat ketiga penelitian yang terdahulu yang telah dilakukan oleh peneliti sebelumnya, ketiganya menggunakan Individual Competence Framework dalam menganalisis kemampuan literasi media pada kalangan mahasiswa dalam penggunaan media. Penelitian-penelitian sebelumnya melihat kemampuan literasi media informan secara keseluruhan tanpa menetapkan kemampuan literasi media pada konten yang lebih spesifik. Sedangkan penelitian yang dilakukan oleh penulis secara spesifik melihat kemampuan literasi media mahasiswa terkait konten yang lebih khusus yaitu bagaimana kemampuan literasi media para responden menyikapi Isu SARA yang kerap beredar di media sosial Facebook.

Data yang didapatkan dari lapangan dipilah kemudian dikelompokkan, dan dianalisis dengan menggunakan individual competence framework. Adapun indikator dalam individual competence faramework yaitu (1) Personal Competence, yaitu kemampuan seseorang dalam menggunakan media dan menganalisis konten-konten media. Personal Competence dibagi menjadi dua yaitu Use Skill, yaitu kemampuan teknik dalam menggunakan media. Artinya seseorang mampu mengoperasikan media dan memahami semua jenis instruksi yang ada di dalamnya. Critical Understanding kemampuan cognitif dalam menggunakan media seperti kemampuan memahami, menganalisis, dan mengevaluasi konten media (2) Sosial Competence, yaitu kemamampuan seseorang dalam berkomunikasi dan membangun relasi sosial lewat media serta mampu memproduksi konten media. Sosial Competence terdiri dari communicative Abilities yaitu kemampuan komunikasi dan partisispasi melalui media ${ }^{18}$. Level of Competence dalam konsep individual competence dapat dilihat pada tabel di bawah ini.

Level B̈asic

\section{Definition}

Basic the Individuai has a set of abilities that allows basic use of the media. There is a limited use of media. The user knows its basic funcion,deciphers its basic codes and uses it for sprcific end and to determine the tool. The user's capacity to critically analilyse the information received is limited. Its communicative capabality through media is also limited.

${ }^{18}$ Juliana Kurniawati \& Sitti Baroroh, "Literasi Media Digital Mahasiswa Universitas Muhammadiyah Bengkulu". Jurnal Komunikator Vol. 8 No. 2 (Novermber 2016). Diakses Tanggal 1 Agustus 2017. 
Medium

Advanced
The individual is fluent in media use, knowing their functions and able to carry out certain, more complex operations. The use of media is extended. The user knows how to obtain and asses the information he/she requires, as well as evaluating (and improving) the information search strategies

The individual is very active in media use being aware of and interested in the legal conditions that affect its use.The user has an in-depth knoledge of the techniques and languages and can analyse (and eventually) transform the conditions affecting his/her communicative relations and the creation of messages. In the social sphere the user is capable of activating coorperation group that allow that allow him/her to solve problem

Sumber: European Commission, 2009.

\section{B. Analisis Literasi Media Mahasiswa Perguruan Tinggi Negeri di Kendari Menyikapi Isu SARA pada Media Sosial}

Dalam rangka mendapatkan data terkait penelitian ini maka penulis melakukan wawancara kepada mahasiswa dari dua perguruan tinggi negeri di kota kendari yaitu IAIN Kendari dan Universitas Haluoleo. Penelitian ini ingin melihat dua permasalahan yaitu kemampuan literasi media mahasiswa perguruan tinggi negeri di Kendari dalam menyikapi isu SARA di media sosial dalam adalah konten sara para media sosial facebook, serta solusi dalam meningkatkan kemampuan literasi media yang berhubungan dengan Isu SARA di media sosial. Pembahasan dibawah ini adalah pemaparan dari kedua fokus permasalahan dalam penelitian ini.

\section{B.1 Kemampuan Literasi Media Mahasiswa Perguruan Tinggi Negeri di Kendari Menyikapi Isu SARA pada Media Sosial}

Dalam pembahasan hasil penelitian ini penulis akan mengkaji beberapa indikator yang disebutkan dalam Individual Competence Framework guna mengetahui tingkat kemampuan literasi media dari informan yaitu personal competence dan social competence dari responden. Personal Competence terdiri dari tecnical skill dan critical understanding.

\section{B.1.1 Technical skill}

Apabila dilihat dari hasil wawancara dengan 20 orang mahasiswa IAIN Kendari dan 20 orang mahasiswa Universitas Haluoleo,dapat dilihat bahwa sebagian besar alasan responden untuk memilih suatu merek smartphone tertentu adalah lebih kepada tampilannya, harga dan kecepatan 
prosessornya. Mereka tidak menitik beratkan pada fitur-fitur yang dimiliki suatu merek tertentu dalam mendukung aktivitas mereka sebagai mahasiswa. Atau keunggulan teknis lainnya yang dimiliki oleh suatu merek tertentu.

Hal tersebut dapat disebabkan karena sebenarnya sebagian besar dari informan menggunakan fasilitas komunikasi dalam hal ini smartphone hanya untuk mengakses media sosial, mengambil gambar (fasilitas kamera), game dan lainnya. Hal ini terlihat dari hasil penelitian yang memperlihatkan bahwa sebagian besar aplikasi yang mereka gunakan dalam perangkat mereka hanya sebatas media sosial saja, atau perangkat pencarian data. Aplikasi untuk dapat mengakses berita dari sumber terpercaya masih sangat kurang sekali yang menggunakannya, sehingga cenderung mereka mendapatkan informasi sebagian besar dari media sosial. Seperti yang kita dapat amati di media sosial saat ini khususnya facebook, berita yang ditampilkan tidak dapat terjamin semuanya merupakan berita yang bebas hoax, sebagian besar berita yang ditampilkan di media sosial adalah jenis clickbait dimana berita jenis ini terkadang hanya mengandalkan sensasi untuk mendapatkan perhatian dan rating dari pembaca. Biasanya berita clickbait menggunakan bahasa atau membuat judul yang sensasional dan provokatif bagi pembaca tetapi isi beritanya tidak relevan dengan judul yang ditampilkan, sehingga butuh kemampuan bagi pembaca/ khalayak media sosial dalam memilah dan menganalisis berita yang mereka dapatkan. Salah menginterpretasi dan memilah pesan akan mengakibatkan salah mengartikan dan salah menyikapi suatu peristiwa atau persoalan.

Banyaknya berita hoax yang beredar di media sosial dapat diakibatkan karena karakteristik media sosial atau media online yang desentralized yang membuat siapa saja bisa mengirimkan pesan kepada siapa saja pengguna media sosial dan bentuk berita pada media online yang tidak harus melewati tahapan gatekeeper sebelum di terbitkan atau ditayangkan bagi khalayak seperti layaknya pada media massa mainstream ${ }^{19}$.

Dari hasil penelitian yang telah dipaparkan diatas dapat dikatakan bahwa kemampuan tecnical skill dari mahasiswa perguruan tinggi di Kota Kendari berdasarakan indikator pada individual competence framework masih berada pada taraf basic/dasar. Dimana mereka mampu mengoperasikan perangkat komunikasi, akan tetapi terbatas hanya menggunakannya sebagian besar untuk kebutuhan media sosial saja. Hal ini juga terlihat dari alasan memilih smartphone dimana sebagian besar memilih perangkat yang memiliki fasilitas yang unggul pada fitur kameranya dan dari segi tampilan smartphonenya.

\footnotetext{
${ }^{19}$ Apriadi Tamburaka, Literasi Media, Op Cit... h.71
} 


\section{B.1.2 Critical Understanding}

Berdasarkan hasil penelitian dapat dilihat bahwa kemampuan dalam memahami, dan memilah-milah pesan yang informan dapatkan menyangkut konten SARA di media sosial sudah cukup baik hal ini berdasarkan dari wawancara yang telah dilakukan oleh penulis dapat dilihat bahwa mereka telah mampu memilah-milah pesan yang mereka temukan, mereka dapat menganalisis mana pesan yang benar dan mana pesan yang hanya merupakan suatu kebohongan atau hoax. Pesan yang mereka anggap sebagai hoax mereka abaikan dan tidak mereka share atau bagikan kepada yang lain. Hal ini merupakan suatu upaya yang meski sederhana tetapi setidaknya dapat menghentikan meluasnya pesan hoax tersebut.

Dapat dilihat juga bahwa mereka memiliki cara-cara tersendiri dalam mencari kebenaran dari pesan-pesan yang mereka terima. Seperti mencari atau melakukan verifikasi pada webside yang lain yang lebih terpercaya.

Dari pendapat yang dikemukakan oleh para informan, peneliti dapat melihat bahwa kemampuan menganalisis konten-konten SARA di media sosial sudah cukup baik, hal ini terlihat pada komentar beberapa informan yang mengatakan bahwa mereka enggan untuk membagikan konten-konten yang berbau SARA yang belum jelas kebenarannya, karena hal itu merupakan hal yang cukup sensitif bagi bangsa Indonesia yang multikultur. Meskipun ada beberapa informan yang tergabung dalam sebuah kelompok kajian agama Islam di Universitas Haluoleo, menyatakan bahwa konten SARA itu perlu dibagikan di media sosial karena hal tersebut cukup penting untuk diketahui dan dapat mengedukasi bagi sebagian orang. Maksud dari mengedukasi yang disebutkan oleh informan adalah agar hal yang serupa tidak terulang kembali. Contohnya saja pada isu kasus penistaan agama yang dilakukan oleh Basuki Tjahaya Purnama (Ahok) beberapa waktu silam dimana pelaku adalah seorang nonmuslim dan beretnis Tionghoa, perlu untuk disebarkan agar tidak terulang lagi dikemudian hari.

Isu SARA menjadi hal yang cukup sensitif karena kerap dijadikan "bahan bakar" untuk mencapai suatu tujuan tertentu. Isu SARA kerap digunakan dalam dunia politik untuk mengangkat citra kandidat maupun menjatuhkan lawan politik. Mengapa Isu SARA merupakan hal yang banyak digunakan. Karena suku, agama, ras, dan golongan merupakan suatu identitas yang melekat pada setiap individu, sehingga Isu SARA menjadi sangat sensitif bagian sebagian besar individu, utamanya di Indonesia yang multietnis dan agama yang beragam. Hal ini mengakibatkan isu SARA menjadi hal yang dapat digunakan untuk menarik perhatian masyarakat ataupun membangun sentiment kelompok atau golongan terentu dalam masyarakat. 
Manusia umumnya mengidentifikasikan diri dengan kelompok dan ideologi kelompok. Kita kemudian melakukan pengelompokan yang berbeda agama, bahkan yang memiliki agama yang sama tetapi berbeda aliran, dapat dianggap berbeda oleh kelompok. Dalam kondisi ada emosi-emosi negatif terjadilah penilaian yang makin bersifat emosional. Kelompok sendiri dianggap lebih dapat dipercaya, kelompok lain dilihat tidak dapat dipercaya dan mengancam. Prasangka mengahadirkan sikap-sikap yang membedakan atau diskriminatif pada kelompok yang dianggap berbeda. Banyaknya konten media yang berisi kebencian dan mengklaim merasa paling benar membuat isu tentang agama sangat sensitif ${ }^{20}$.

Berdasarkan hasil penelitian dapat dilihat bahwa responden masih belum melakukan tindakan evaluasi terhadap konten-konten SARA yang mereka terima. Sebagian besar dari informan hanya sebatas dapat memilah dan menganalisis konten-konten SARA yang mereka temuai di media sosial dan tidak menyebarluaskannya dan berhenti sampai disitu. Mereka tidak melakukan evaluasi terhadap bagaimana perkembangan konten-konten tersebut seperti bagaimana dampaknya dan memberikan kritikan terhadap konten-konten yang merugikan, dan upaya-upaya lainnya. Padahal kemampuan literasi media seperti yang dikatakan oleh Tapio Varis ${ }^{21}$ mendefenisikan literasi media sebagai sarana demokratisasi, Varis menyatakan bahwa kemampuan dalam menganalisis, meneliti dan mengevaluasi media merupakan hal yang penting diketahui oleh masyarakat agar supaya masyarakat menjadi lebih demokratis. Masyarakat bebas untuk memberikan kritisi terhadap tayangan-tayangan yang mereka konsumsi. Khalayak yang berada pada masyarakat otoriter dan sosialis akan sulit melakukan hal tersebut, karena tayangan yang mereka konsumsi telah diatur oleh pemerintah sehingga jenis tayangan yang mereka dapatkan tidak beragam dan kesempatan untuk melakukan kritik terhadap informasi yang didapatkan dibatasi atau tidak memiliki kesempatan sama sekali.

Oleh karena itu peneliti menganggap bahwa kemampuan critical understanding dari mahasiswa perguruan tinggi negeri di Kota Kendari masih berada pada tahap basic atau dasar, masih perlu ditingkatkan.

\section{B.1.3 Sosial Competence}

Sosial Competence, yaitu kemamampuan seseorang dalam berkomunikasi dan membangun relasi sosial lewat media serta mampu

\footnotetext{
${ }^{20}$ Poerwandari, Rubrik... Op Cit, h. 25

${ }^{21}$ Apriadi Tamburaka, Literasi Media, Op Cit... h. 9
} 
memproduksi konten media. Sosial Competence terdiri dari communicative Abilities yaitu kemampuan komunikasi dan partisispasi melalui media ${ }^{22}$.

Membangun komunikasi dengan menggunakan media sosial adalah trend pada kalangan muda saat ini. mereka lebih senang berkomunikasi dengan menggunakan media sosial dibandingkan secara face to face. Hal ini dapat dikaitkan dengan pendapat peneliti media baru Himanshu Tyagi dan Scott E.Caplan yang mengatakan bahwa, generasi muda kurang memiliki keahlian sosial memadai dan gagap berkomunikasi tatap muka. Mereka akan berpaling kepada e-mail, telefon selular dan media sosial sebagai cara paling jitu untuk menyenangkan dan menggairahkan dalam membina hubungan $\operatorname{sosial}^{23}$. Hal senada juga dikatakan oleh J.B. Walther yang mengatakan bahwa, aktivitas komunikasi sosial dengan perantara komputer dianggap lebih memikat dari pada berkomunikasi secara face to face.

Berdasarkan hasil penelitian dapat dilihat bahwa dalam menjalin relasi pertemanan dan komunikasi melalui media sosial telah dilakukan dengan baik oleh para informan. Hal ini terlihat dari jumlah pertemanan mereka di facebook mencapai kisaran ribuan orang. Mereka juga merasa lebih mudah dalam berkomunikasi melalui media sosial. mereka juga menjadikan media sosial sebagai ajang aktualisasi diri dengan cara memajang foto-foto dan mengabarkan aktivitas mereka. Akan tetapi mereka belum mampu untuk menyatakan pendapat mereka tentang sesuatu hal, atau menanggapi tentang suatu peristiwa dari sudut pandang mereka. Hal ini memperlihatkan bahwa kemampuan mereka untuk memproduksi pesan masih sangat minim. Bentuk perilaku bermedia sosial mereka lebih kepada membagikan pesan-pesan yang dianggap penting bagi mereka dan temanteman mereka di media sosial. Produksi pesan yang disampaikan hanya sebatas menceritakan keseharian mereka ataukah memposting foto-foto mereka. Sehingga bisa dikatakan bahwa media sosial sebagai ajang aktualisasi diri mereka. Oleh karena itu peneliti menganggap sosial acceptence mereka belum sempurna, masih berada pada taraf basic atau dasar.

\section{B.2 Solusi dalam meningkatkan kemampuan literasi media mahasiswa perguruan tinggi negeri di Kendari}

Pernyataan yang sering kita dengar saat ini, bahwa Indonesia sedang berada pada masa darurat hoax. Oleh karena itu salah satu cara yang dapat

\footnotetext{
${ }^{22}$ Kurniawati, Juliana dan Baroroh, Siti. Literasi Media ... Op Cit.

${ }^{23}$ Idi Subandi Ibrahim, Komunikasi dan Komodifikasi. (Jakarta:Yayasan Pustaka
} Obor Indonesia, 2014), h. 2 
ditempuh untuk menekan penyebaran hoax adalah terus meningkatkan kemampuan literasi media khalayak dalam hal ini masyarakat Indonesia. Salah satu cara yaitu dengan memasukkan pendidikan literasi media ini kedalam kurikulum pembelajaran seperti pada pendidikan anti korupsi dan pancasila. Materi tentang literasi media tidak hanya untuk mahasiswa komunikasi saja, akan tetapi kepada seluruh mahasiswa yang berlatar belakang ilmu lainnya seperti tarbiyah, ekonomi, hukum, teknik, kesehatan dan lain-lain. Hal ini akan lebih memperkaya khazanah ilmu tersebut karena kajian ilmu literasi media tersebut tidak hanya pada tataran komunikasi tetapi sudah berkembang dan dapat masuk pada perspektif ekonomi, hukum, mauapun pendidikan. Pada bidang tarbiyah atau pendidikan dan keguruan, dengan ditingkatkannya kemampuan literasi media mahasiswanya, akan diteruskan kepada anak didiknya. Beberapa usaha yang dapat dilakukan sebagai solusi dalam meningkatkan literasi media mahasiswa perguruan tinggi negeri adalah menggiatkan penelitian pada bidang literasi media dan pengabdian kepada masyarakat, menggiatkan pelatihan tentang literasi media kepada semua kalangan, membentuk komunitas-komunitas penyuluhana tentang literasi media, cara bijak dalam menggunakan media sosial kepada masyarakat baik itu di kalanggan mahasisiswa itu sendiri maupun dikalangan masyarakat yang rentan seperti kaum perempuan dan anak-anak atau remaja. Peran opinion leader baik itu tokoh agama dan tokoh masyarakat. Di IAIN Kendari kerap dilakukan pengajian rutin yang dilakukan oleh beberapa dosen Fakultas Ushuluddin adab dan dakwah khususnya dosen ilmu quran dan tafsir, selain mengkaji tentang $\mathrm{Al}$ quran, juga banyak menyelipkan tentang bagaimana bijak dalam menggunakan media sosial, dalam Al Quran kerap di sebut dengan Tabayyun. Tabayyun merupakan proses pencarian kejelasan hakekat sesuatu atau kebenaran suatu fakta dengan teliti, seksama dan hatihati ${ }^{24}$. Apabila dikaitkan dengan pembahasan mengenai literasi media, tabayyun dilakukan agar dapat memilah-milah informasi yang diterima melalui media agar tidak terprovokasi oleh berita-berita yang tidak bertanggung jawab yang akan memecah belah persatuan dan kesatuan bangsa dan keharmonisan antar umat beragama ${ }^{25}$.

Pemaparan diatas mengenai solusi guna meningkatkan literasi media mahasiswa perguruan tinggi negeri di Kota Kendari sesuai dengan paparan oleh Apriadi Tamburaka yang menjelaskan bahwa literasi media juga disepakati sebagai kegiatan yang berjenjang. Pembagian tingkat ini tidak lain bertujuan agar dapat memudahkan para penggiat literasi media dalam

\footnotetext{
${ }^{24}$ Erwan Efendi. "Tabayyun dalam Jurnalistik”, Jurnal Komunika Islamika: Jurnal Ilmu Komunikasi dan Kajian Islam, Vol.3 No.3 (2016).
} 
merancang materi kegiatan dengan tiga tingkat ${ }^{26}$ yaitu: (1) Awal, pada tingkat awal dapat diberikan materi berupa jenis kategori, fungsi, pengaruh, dan penggunaan media. (2) Menengah, pada tingkat menengah, materi yang dapat diberikan adalah pemahaman tentang baik-buruk, proses produksi, fakta-fiksi, dan pengaruh iklan dalam media. (3)Tinggi, pada tingkat lanjut, materi yang diberikan dalam kegiatan literasi media menyangkut industri, etika, regulasi, kritik, bahkan memproduksi media alternatif.

Untuk menjangkau target dari kegiatan literasi media, dapat dilakukan melalui kegiatan ekstrakurikuler, kelompok, komunitas, opinion leader, atau integrasi ke dalam mata pelajaran di sekolah atau perguruan tinggi. Pada saat mempopulerkan atau mengsosialisasikan isu ini kepada khalayak, maka dapat dikaitkan dengan isu-isu seperti kewarganegaraan, ekonomi, pluralisme, lingkungan, demokrasi, kesehatan, korupsi, dan lain sebagainya.

Dalam mengevaluasi program kegiatan literasi media, para penggiat dapat mengukurnya melalui ketiga dimensi yaitu (1) Dimensi Motivasi, mengacu pada tindakan bermedia seseorang atau sebuah kelompok (tergantung kegiatan). Pada bagian ini, dapat diketahui tujuan seseorang dalam mengakses media; kesadaran atas manfaat media; strategi pencairan informasi; serta kemampuan dalam memahami fungsi-fungsi media.(2) Dimensi Pengetahuan, dapat diterjemahkan sebagai sebuah pemahaman yang dimiliki seseorang atau kelompok. Dalam kaitannya dengan literasi media, pengetahuan dapat berarti pemahaman terhadap proses komunikasi massa; pemahaman terhadap karakteristik media (produksi, gramatika, dan rutinitas); pemahaman terhadap dampak media massa; pemahaman terhadap kontribusi media pada budaya kontemporer; dan pemahaman terhadap konstruksi realita yang dilakukan oleh media.(3) Dimensi Keterampilan, terdapat kemampuan untuk menganalisis, mengevaluasi, mengkomunikasikan, mengategorikan, memadukan, dan mengkritisi media. Analisis evaluasi, komunikasi, kategorisasi, dan panduan merupakan pencapaian yang akan dapat dilakukan dengan lebih baik jika seseorang memiliki skill. Sementara, pada level advance diharapkan dapat memiliki kemampuan dalam mengkritisi media dan melakukan sesuatu yang berdampak kepada khalayak media. Misalnya, melaporkan konten media bermasalah ke lembaga terkait.

Evaluasi terhadap program kegiatan literasi media dilakukan dengan melibatkan dimensi-dimensi di atas. Kegiatan evaluasi ini berfokus pada dua hal, yaitu: (1) tingkat keberhasilan pelaksanaan atau pengelolaan program dan (2) tingkat keberhasilan media literasi ditengah peserta atau partisipan

${ }^{26}$ Apriadi Tamburaka, Literasi Media, Op Cit h. 73 
program. Fokus Kedua dapat diukur dengan melihat tingkat literasi media yang dimiliki peserta atau partisipan yang telah mengikuti program.

\section{Penutup}

Kemampuan literasi media dapat diketahui dengan menggunakan Individual competence framework yang terdiri dari tecnical skill, critical understanding, dan sosial competence. Kemampuan tecnical skill mahasiswa perguruan tinggi negeri di Kota Kendari masih berada pada taraf basic/dasar, dimana mereka telah dapat mengoperasikan perangkat media komunikasi baik laptop maupun smartphone dengan baik akan tetapi masih pada tataran dasar. Misalnya menggunakan perangkat komunikasi mereka hanya untuk mengakses media sosial, mengambil foto dan aplikasi-aplikasi dasar lainnya. Kemampuan critical understanding informan masih berada pada tahap basic dimana mereka telah mampu memilah kemudian menganalisis konten konten SARA yang mereka jumpai di media sosial. Hal ini terlihat apabila mendapatkan berita atau kabar yang menyangkut isu SARA mereka tidak langsung membagikan kabar tersebut. Mereka terlebih dahulu memilah dan menganalisis pesan-pesan yang mereka dapatkan sebelum membagikannya. Hanya saja kemampuannya masih terbatas, mereka belum mampu mengevaluasi konten-konten SARA yang mereka jumpai di media sosial.

Kemampuan Sosial competence dari para informan terlihat bahwa mereka telah mampu membangun jaringan di media sosial, terlihat dari banyaknya jumlah pertemanan mereka di media sosial, baik dari lingkup keseharian mereka maupun dengan orang-orang yan tidak pernah mereka temui sebelumnya. Akan tetapi kemampuan mereka untuk membangun konten media sosial masih kurang, karena sebagian besar informan hanya membaca postingan di media sosial tetapi jarang untuk menuliskan postingan tentang pendapat mereka mengenai suatu hal . Sebagian besar informan menuliskan postingan di media sosial apabila terkait hal yang sangat penting dan menarik bagi mereka. Sebagian mereka hanya membangun pesan untuk aktualisasi diri mereka dalam menggunakan media sosial atau menuliskan pesan-pesan mengenai aktivitas mereka sehari-hari, seperti memasang foto selfi dan lain sebagainya. Kemampuan untuk beragumen terhadap suatu peristiwa atau permasalahn tertentu masih sangat kurang. Berdasarkan analisis tersebut disimpulkan bahwa kemampuan literasi media mahasiswa perguruan tinggi negeri di Kota Kendari berdasarkan indikator pada Individual competence framework berada pada tingkat basic/dasar dimana pada taraf ini berdasarkan level of competence the Individual has a set of abilities that allows basic use of the media. There is a limited use of media. The user knows its basic funcion,deciphers its basic 
codes and uses it for sprcific end and to determine the tool. The user's capacity to critically analilyse the information received is limited. Its communicative capabality through media is also limited.

Melalui penelitian ini dapat diketahui bahwa tingkat kemampuan literasi media mahasiswa IAIN Kendari dan Universitas Haluoleo Kendari dalam menyikapi konten-konten yang berbau SARA di media sosial masih berada pada tataran basic atau dasar seperti pada penjelasan diatas. Penelitian ini lebih spesifik kepada kemampuan literasi media informan terhadap Isu SARA. Melihat isu SARA di media sosial terutama facebook sangat marak dan dapat membawa dampak perpecahan bagi masyarakat Indonesia yang memiliki agama dan budaya yang beragam. Berbeda dengan penelitian literasi media terdahulu yang tidak memfokuskan penelitiannya pada konten media tertentu, sehingga penelitian ini lebih spesifik dibandingkan dengan penelitian literasi media lainnya.

Solusi dalam meningkatkan kemampuan literasi media khususnya mengenai isu SARA dikalangan mahasiswa perguruan tinggi di Kota Kendari yaitu dengan memasukkan pengetahuan mengenai literasi media pada kurikulum pendidikan disetiap program studi, melakukan penelitian terkait literasi media di kalangan dosen maupun mahasiswa dan dapat dilakukan dari berbagai perspektif ilmu. Mengadakan pelatihan dan workshop terkait kemampuan literasi media, khususnya di kalangan mahasisiwa,baik yang diadakan di lingkup kampus, maupun diluar lingkup kampus, memberikan pengetahuan literasi media melalui opinion leader baik itu pemuka agama ataupun tokoh masyarakat, mengembangkan kajian-kajian agama di kampus. Dalam kajian tersebut dapat diselipkan pengetahuan literasi media dari sudut pandang agama.

Semakin banyak dilakukan pelatihan atau workshop yang bertujuan untuk meningkatkan kemampuan literasi media masyarakat, baik yang diadakan oleh pemerintah maupun swasta. Hendaknya pemerintah membuat peraturan yang lebih ketat lagi dan sanksi yang cukup berat bagi kejahatan penyebaran hoaks maupun konten-konten yang tidak bertanggungawab di media sosial. Adanya pencerahan kepada masyarakat tentang kostruksi yang dilakukan oleh media agar tidak terlalu cepat terprovokasi terkait isu-isu SARA yag memang menjadi isu yang sangat sensitif di masyarakat saat ini, masyarakat harus mamapu memilah berita karena banyaknya berita hoax yang beredar. Diharapkan lebih banyak lagi peneliti baik dosen maupun mahasiswa khususnya pada program studi komunikasi penyiaran Islam yang meneliti masalah literasi media. Hasil penelitian dapat dijadikan rekomendasi dalam menghadapi perilaku masyarakat pengguna media sosial terlebih saat ini Indonesia berada pada masa darurat hoax. 


\section{DAFTAR PUSTAKA}

Budiargo, Dian. Berkomunikasi Ala Net Generations. Jakarta, PT. Elex Media Kompetindo, 2015

Fauzi, Ahmad "Memahami Literasi Media Baru dalam Penyebaran Informasi Hoax dan Hate Speech (Studi Fenomenologi Dosen Pengguna Facebook dan Whatsapp)", PROMEDIA, Vol 4, No. 2, (2018): 56 76

Fitryarini, Inda "Literasi Media Pada Mahasiswa Prodi Ilmu Komunikasi Universitas Mulawarman", Jurnal Komunikasi Vol. 8, No. 1, (Juli 2016): $51-67$

Efendi, Erwan "Tabayyun dalam Jurnalistik", Jurnal Komunika Islamika: Jurnal Ilmu Komunikasi dan Kajian Islam, Vol.3 No.3 (2016).

Harahap, Barkah Hadamean "Poda Na Lima Sebagai Konsep Literasi Media Dalam Memfilterisasi Berita Hoax (Studi Pada Dosen dan Mahasiswa Fakultas Dakwah dan Ilmu Komunikasi IAIN Padangsidimpuan)", TAZKIR: Jurnal Penelitian Ilmu-Ilmu Sosial dan Keislaman Vol. 04 No. 2 (Desember 2018): 363-380.

Harianto, Gun Gun. Media Komunikasi Politik. Yogyakarta. IRCISod, 2018

Ibrahim, Idi Subandi Komunikasi dan Komodifikasi. Jakarta: Yayasan Pustaka Obor Indonesia, 2014

Kurniawati, Juliana \& Baroroh, Siti. "Literasi Media Digital Mahasiswa Universitas Muhammadiyah Bengkulu". Jurnal Komunikator Vol.8 No.2 (November 2016): 51-66

Mahendra, David. Media Jejaring Sosial dalam Dimensi Self Disclosure. Yogyakarta: Skripsi UIN Sunan Kalijaga, 2014

Poerwandari. "Rubrik Psikologi”. Harian Kompas. Sabtu, 29 Juli 2017

Poerwaningtias, Intania dkk. Model-Model Gerakan Literasi Media dan Pemantauan Media di Indonesia. PKBP Yogyakarta. 2013. 
Prasetiyo, Wibowo Heru \& Gunarsi, Sri "Fabrikasi Fitnah Dan Gerakan Dakwah Pemuda: Penguatan Literasi Media Dan Pengelolaan Media Sosial Pada Organisasi Kepemudaan Masjid Forsam Klaten Selatan", The 9th University Research Colloqium Universitas Muhammadiyah Purworejo, 2019: 54-63

Purba, Rebekka "Tingkat Literasi Media Pada Mahasiswa (Studi Deskriptif Pengukuran Tingkat Literasi Media Berbasis Individual Competence Framework Pada Mahasiswa Departemen Ilmu Komunikasi USU)", Jurnal Flow, Vol 2, No 9 (2015): 1-10.

Rahadi, Dedi Rianto. "Perilaku Pengguna dan Informasi Hoax di Media Sosial”. Jurnal Manajemen \& Kewirausahaan, Vol. 5, No. 1 (2017): $58-70$

Rahmawati, Aulia \& Krisanjaya. "Pelatihan Literasi Media Dengan Metode Getok Tular Mulut Ke Mulut (Strategi Word Of Mouth Comunication) Untuk Antisipasi Ujaran Kebencian (Hate Speech) Se Kota Depok Provinsi Jawa Barat", Sarwahita : Jurnal Pengabdian Kepada Masyarakat Vol. 15 No. 2 (2018): 106-112

Sulthan, Muhammad \& Istiyanto, S. Bekti. "Model Literasi Media Sosial Bagi Mahasiswa", Jurnal ASPIKOM, Vol 3 No 6, (Januari 2019): 1076-1092

Tamburaka, Apriadi. Literasi Media, Cerdas Bermedia Khalayak Media Massa. Jakarta: Rajawali Pers. 2013

Zubaidi, Advan Navis "Urgensi Literasi Media di Tengah Sinisme Antarsuku, Agama, Ras, dan Golongan", Jurnal Komunikasi Islam Vol 08, No 01, (Juni 2018): 111-128 